\title{
Influence of somatic cell count and total bacterial counts of raw milk in cheese yield using small-scale methodology
}

\author{
[Influência da contagem de células somáticas e da contagem bacteriana total do leite cru no \\ rendimento da produção de queijos, utilizando metodologia em escala reduzida]
}

N.M.A. Silva, L.P.F. Bastos, D.L.S. Oliveira, M.C.P.P. Oliveira, L.M. Fonseca

Escola de Veterinária - Universidade Federal de Minas Gerais - Belo Horizonte, MG

\begin{abstract}
The objectives of this study were to evaluate the influence of SCC and TBC of raw milk in cheese yield, using a reduced scale method, and to evaluate theoretical prediction of cheese yield. 270 samples of raw milk were split into three SCC levels (below 200,000; 200,000-750,000; above 750,000 SC/mL) and three TBC levels (below 100,000; 100,000-750,000; above 750,000 CFU/mL). Raw milk samples were submitted to compositional analysis (fat, protein, lactose, total solids and SNF content), SCC, TBC, freezing point and $\mathrm{pH}$. The production of the small-scale cheese was conducted according to the method developed at Cornell University (Melilli et al., 2002). Cheese whey samples were submitted to compositional analysis (fat, total protein, true protein, lactose, total solids and SNF content) and SCC. The increase in the SCC of raw milk resulted in increased protein loss in cheese whey. High SCC (above $200,000 \mathrm{SC} / \mathrm{mL}$ ) in milk samples was correlated to reduced dry matter yield. There was no effect of TBC in cheese yield in the experimental conditions used. There was a high correlation between the theoretical yield values and the yield values predicted by the small-scale method, indicating that this method is appropriate for cheese yield prediction.
\end{abstract}

Keywords: raw milk, SCC, TBC, yield

\section{RESUMO}

Este trabalho teve como objetivos verificar a influência da CCS e CBT do leite cru no rendimento de queijos, utilizando método em escala reduzida, e avaliar a predição teórica do rendimento de queijos. Foram utilizadas 270 amostras de leite cru com três níveis de CCS (abaixo de 200.000; 200.000750.000; acima de $750.000 \mathrm{CS} / \mathrm{mL}$ ) e três níveis de CBT (abaixo de 100.000; 100.000-750.000; acima de $750.000 \mathrm{UFC} / \mathrm{mL}$ ). As amostras de leite cru foram submetidas a análises de composição (gordura, proteína, lactose, EST e ESD), CCS, CBT, crioscopia e pH. A produção dos queijos em escala reduzida foi feita segundo o método desenvolvido na Universidade de Cornell, EUA (Melilli et al., 2002). As amostras de soro de queijo foram submetidas a análises de composição (gordura, proteína total, proteína verdadeira, lactose, EST e ESD) e CCS. O aumento da CCS no leite cru refletiu na maior perda de proteína no soro. CCS elevada (acima de $200.000 \mathrm{CS} / \mathrm{mL}$ ) foi correlacionada ao menor rendimento de massa seca. Foi encontrada uma correlação alta entre os valores teóricos de rendimento e os valores de rendimento preditos pela metodologia em escala reduzida, indicando que esta metodologia pode ser utilizada para a predição do rendimento de queijos.

Palavras-chave: leite cru, CCS, CBT, rendimento

\section{INTRODUCTION}

With an increase in Brazilian milk production and expanding internal and exporting demands,

Recebido em 15 de maio de 2012

Aceito em 10 de setembro de 2012

E-mail: naiarasilva@yahoo.com.br raw milk quality is an essential factor for the dairy sector. Milk quality provides not only safe products, but also more processing yield, extended shelf life and better flavor for milk and derivatives. 
Milk quality is defined by several factors, and among them are major components (fat, protein and lactose content), somatic cell count (SCC), total bacterial counts (TBC), integrity and safety (no adulteration and no drug residues), sensorial quality and storage temperature (Monardes, 1998).

Cheese yield and quality are major concerns for the cheese industry, since they directly affect profits and market expansion (Hicks et al., 1986). According to Sousa et al. (2007), loss of milk quality results in additional costs for processing, due to lower yield, manufacturing difficulties and losses of the final product. Additionally, the production of high value products may be impaired.

Raw milk quality monitoring may also be a tool to estimate cheese yield by the industry, as yield may be influenced by several factors such as milk composition, somatic cell count and microbial contamination, thermal treatment and renneting type (Fenelon and Guinee, 1999). Several authors have evaluated theoretical cheese yield based on some of these factors (Van Slyke and Publow, 1921; Emmons et al., 1990; Melilli et al., 2002). Retention of milk components in the curd is a more accurate yield index, since high component loss in cheese whey will impact profitability.

Theoretical cheese yield may be estimated by the contents of fat, casein or milk protein through calculations such as the Van Slyke formula (Van Slyke and Publow, 1921). However, for small dairies, precise and fast fat and protein determination through chemical methods or infrared equipment is not always a feasible or economical option. For these situations, an empirical method in a reduced scale to predict cheese yield using simple equipment was developed at Cornell University (Melilli et al., 2002).

The objectives of this study were to evaluate the influence of SCC and TBC of raw milk in cheese yield, using a reduced scale method, and to evaluate theoretical prediction of cheese yield.

\section{MATERIAL AND METHODS}

Milk of normal composition, totalizing 270 raw milk samples, were collected based on three levels of SCC (below 200,000; 200,000-750,000; above $750,000 \mathrm{SC} / \mathrm{mL}$ ) and three levels of $\mathrm{TBC}$ (below 100,000; 100,000-750,000; above $750,000 \mathrm{CFU} / \mathrm{mL})$. The experimental treatments involved the combination of all SCC and TBC levels, totalizing 9 experimental groups, with 30 samples each.

Samples were randomly chosen from bulk tank milk samples destined for quality analysis, from May to September 2011. For compositional analysis, $\mathrm{pH}$ and freezing point analysis, samples were previously added of bronopol (2-bromo-2nitro-1,3-propanodiol, natamycin and $\mathrm{pH}$ indicator) as preservative in a $40 \mathrm{~mL}$ collecting bottle. Compositional criteria for sample acceptance were based on the following contents: fat (3.0 to $4.5 \mathrm{~g} / 100 \mathrm{~g}$ ), protein (2.9 to 4.0 $\mathrm{g} / 100 \mathrm{~g})$, lactose $(4.2$ to $5.3 \mathrm{~g} / 100 \mathrm{~g}$ ), non-fat solids (SNF) (above $8.4 \mathrm{~g} / 100 \mathrm{~g}$ ). A second sample was obtained in a $40 \mathrm{~mL}$ sterile collecting bottle added of azidiol (sodium azide, chloramphenicol, ethanol, sodium citrate and bromophenol blue) and was destined to total bacterial counts.

Samples were stored under refrigeration $\left(4^{\circ} \mathrm{C} \pm 1^{\circ} \mathrm{C}\right)$ for up to three days before use for analysis and curd formation. Milk analysis included composition by Fourier transform infrared (fat, protein, lactose, total solids and SNF) and SCC by flow cytometry using CombiScope FTIR $400^{\circledR}$ (Delta Instruments/Advanced, Drachten, The Netherlands), freezing point by thermistor cryoscopy Laktron (Laktron, Londrina, Brazil), $\mathrm{pH}$ (pHmeter Tecnopon ${ }^{\circledR}$, mPA-21; Tecnopon, Piracicaba, Brazil) and bacterial analysis (TBC) by flow cytometry using BactoCount IBC $^{\circledR}$ (Bentley Instruments, Chaska, USA) (Bentley..., 2002). Cheese whey analysis included composition by Fourier transform infrared (fat, total protein, true protein, lactose, total solids and SNF) and SCC by flow cytometry using CombiScope FTIR $400^{\circledR}$ (Delta Instruments/Advanced, Drachten, The Netherlands). Compositional values were used to calculate curd retention of solid components and to calculate cheese yield.

Cheese production was simulated in a smallscale method devised by Melilli et al. (2002), with slight modifications. After analysis, $25.00 \mathrm{~g}$ of each sample were transferred to a $50 \mathrm{~mL}$ 
Falcon tube previously dried and weighted. $300 \mu \mathrm{L}$ of acetic acid (Quimex, São Paulo, Brazil) were added to the milk to decrease $\mathrm{pH}$, followed by manual agitation during 20 seconds and $\mathrm{pH}$ analysis. After acidification, the samples were kept in an agitating water bath (Solab ${ }^{\circledR}$ SL$155 / 22$, Piracicaba, Brazil) for 10 minutes at $35^{\circ} \mathrm{C}$ to reach uniform temperature in the entire content, then added of diluted commercial liquid rennet (HA-LA ${ }^{\circledR}$, Chr. Hansen, Valinhos, Brazil), according to the manufacturer's instructions and manually agitated during 20 seconds. Milk coagulation time was set for 30 minutes at $35^{\circ} \mathrm{C}$ in an agitating water bath. Renneted milk gel was centrifuged at $1630 \mathrm{~g}$ during 30 minutes at $15^{\circ} \mathrm{C}$ in a refrigerated centrifuge $\left(\mathrm{Sigma}{ }^{\circledR}, 3 \mathrm{~K} 30\right.$, with angular rotor model 12159H; Sigma, Harz, Germany). The cheese whey in the supernatant layer was transferred to a sterilized $40 \mathrm{~mL}$ flask and analyzed with CombiScope FTIR $400^{\circledR}$ (Delta Instruments/Advanced, Drachten, Netherlands). The precipitated curd was transferred to previously weighted stainless steel weighing plates, spread and dried during four hours at $100^{\circ} \mathrm{C} \pm 2^{\circ} \mathrm{C}$ (Quimis, Q317B, Diadema, Brazil). After drying, the content was cooled in desiccator and weighted (Marte AY220, Shimadzu, Japan). Dry matter yield was calculated as ratio of dry curd and raw milk weights (Melilli et al., 2002). Dry matter yield and milk and whey composition were used to calculate yield based on component retention.

The experiment was a completely randomized 3 x 3 factorial design (three SCC levels and three TBC levels). Results were submitted to descriptive statistics and analysis of variance (ANOVA), using SAEG v.2007 (UFV, Viçosa, Brazil) and Minitab 16.0 (Minitab ${ }^{\circledR}$, USA). SCC and TBC results were transformed to obtain normal distribution of the data. Multiple comparison between treatments was done by Duncan test $(\mathrm{p}<0.05)$, according to Sampaio (2002). A predicting equation for yield was done based on quality data of composition, SCC and TBC.

\section{RESULTS AND DISCUSSION}

Raw milk components were in accordance to legal requirements (Brazil, 2011). The freezing point of milk samples ranged from $-0.528^{\circ} \mathrm{C}$ to - $0.536^{\circ} \mathrm{C}$. Lower freezing point values were found in samples with high SCC, indicating a modified qualitative composition of milk. Acidity expressed as $\mathrm{pH}$ ranged from 6.45 to 6.86 , in fresh milk (Venturini et al., 2007). Results for whey components are presented in Table 1.

The increase in total protein and true protein content in cheese whey was correlated to higher SCC, but not to TBC (Figure 1). This may be a result of higher content of serum proteins together with loss of milk protein in the whey. The final result is lower cheese yield. The increase in serum proteins of the milk is a consequence of loss of permeability selectivity in the mammary gland as consequence of mastitis.

Table 1. Composition of cheese whey obtained from cheese processed through a small-scale empirical method

\begin{tabular}{lcc} 
Component & $\begin{array}{c}\text { Concentration } \\
(\mathrm{g} / 100 \mathrm{~mL})\end{array}$ & $\begin{array}{c}\text { Reference } \\
\text { values* }\end{array}$ \\
\hline Fat & $0.01-0.08$ & 0.05 \\
Total protein & $0.94-1.48$ & - \\
True protein & $0.69-1.16$ & 0.7 \\
Lactose & $4.36-5.03$ & 4.9 \\
Total solids & $6.46-7.22$ & 6.35 \\
Solids non fat & $6.11-7.11$ & 6.3 \\
\hline *(Smithers et al., 1996) & &
\end{tabular}

Similar findings were reported by Conney et al. (2000) during Swiss cheese production. High SCC in milk was correlated with increased protease content, lower total protein in the cheese and more protein loss in the cheese whey.

Milk samples with high SCC, and the whey obtained from them, presented lower lactose content (Figure 2). This finding was also reported by Vianna et al. (2008), and the same tendency is observed in the cheese whey, since lactose is a soluble component. The higher lactose content of the whey when compared to the milk is due to proportional difference, as other milk solid components were retained in the curd. The regression equation found was: Lactose $(\mathrm{g} / 100 \mathrm{~g})=5.45-0.152(\log \mathrm{SCC} / \mathrm{mL})$. 


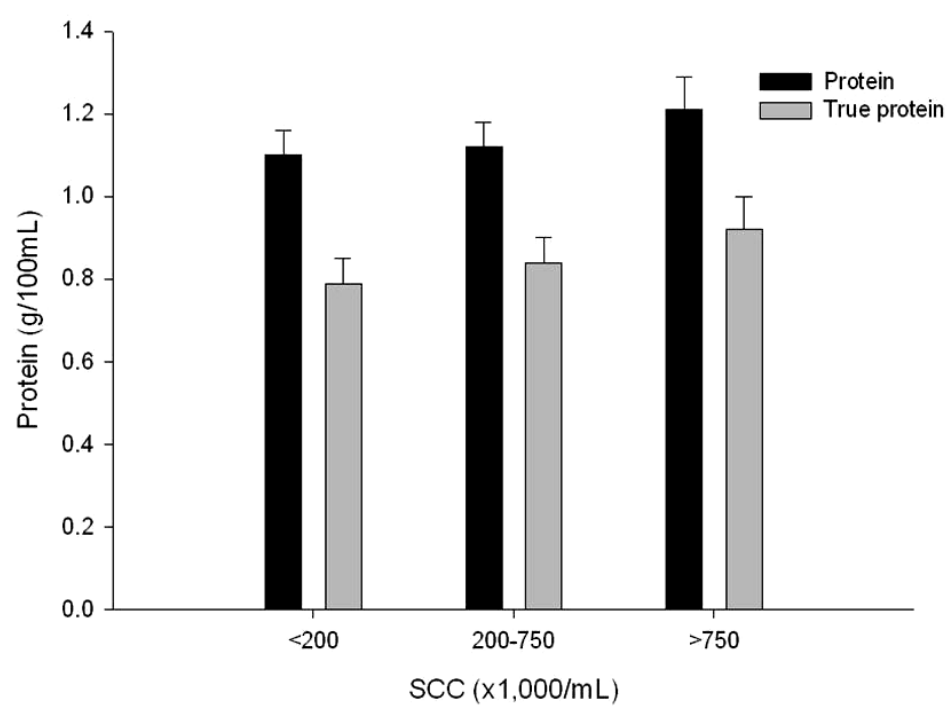

Figure 1. Total protein and true protein $(\mathrm{g} / 100 \mathrm{~mL})$ of cheese whey obtained from cheese processed by a small-scale empirical method, according to SCC range of raw milk.

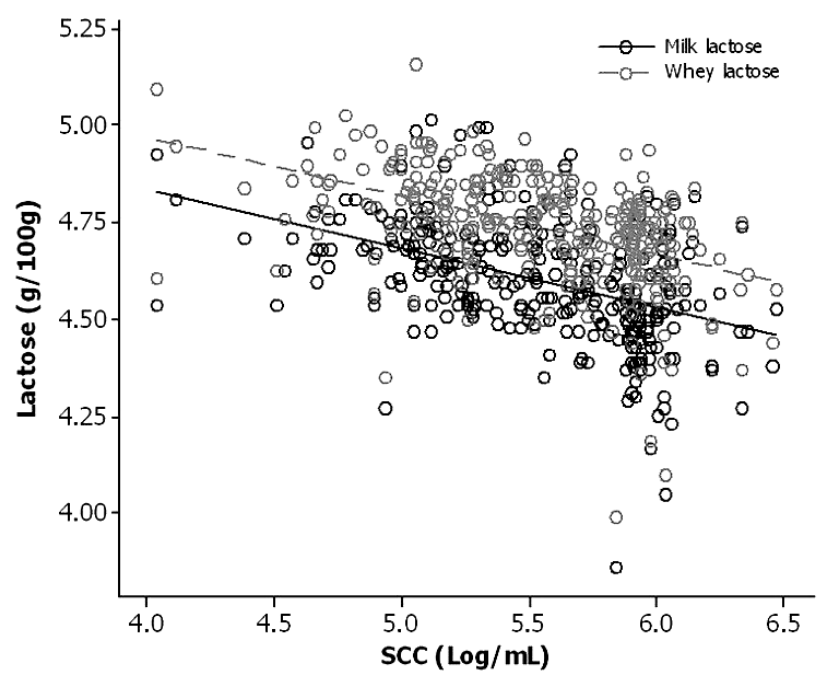

Figure 2. Scatter plot of lactose content of milk and cheese whey produced from it, according to somatic cell count (SCC).

SCC in the cheese whey was low, and this was not reported before. Two major reasons for this low SCC in the whey may be related primarily to the physical binding of cells in the three dimensional structure of the gel, and secondly to the centrifugal force for the whey separation. This is an important finding, since the somatic cells will bound to the curd and high SCC will be more prone to affect the cheese, since somatic cell-mediated local elevation of plasmin activity may be related to extensive caseinolysis (Weng et al., 2006).
SCC and TBC did not affect fat, total solids and non-fat solid content in the cheese whey. Higher serum protein concentration might have counterbalanced the lower synthesis of milk protein, and this will reflect in the total amount of solids in the milk. The fat content of the whey was not affected, but the amount of fat in the whey was low, since the major portion was physically bounded to the precipitated gel.

Dry mass yield ranged from 5.7 to $8.9 \%$. Higher SCC was correlated with lower yield (Figure 3). 


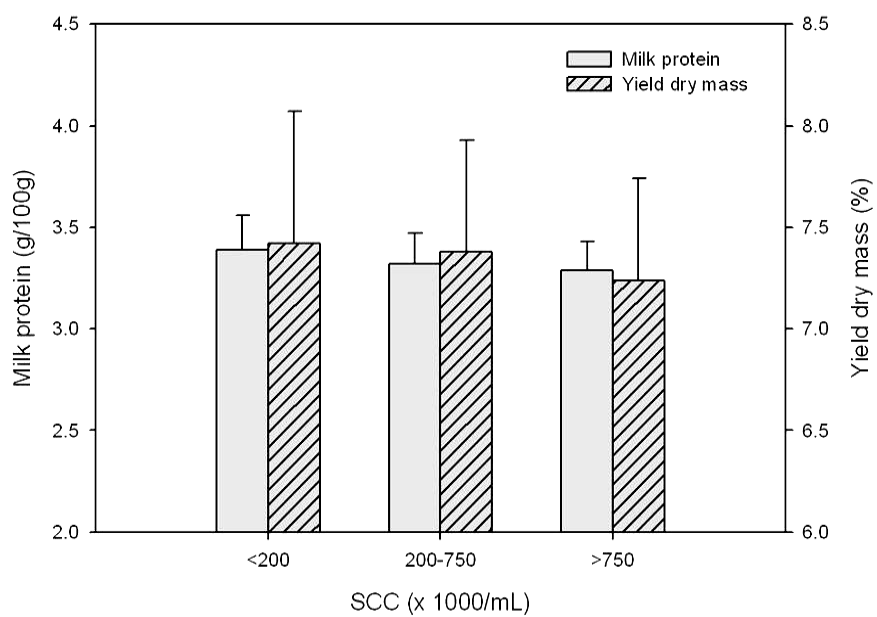

Figure 3. Raw milk protein and yield of dry mass of cheese produced from milk with different ranges of somatic cell count (SCC).

High SCC significantly $(\mathrm{p}<0.05)$ affected cheese yield, as cited by other authors (Matioli et al., 2000). Vieira (2010), for example, reported yield losses of more than $15 \%$ with high SCC in raw milk during the production of Minas cheese, a typical Brazilian fresh cheese. Raw milk with SCC levels of $100,000-250,000 \quad \mathrm{SC} / \mathrm{mL}$; $400,000-750,000 \mathrm{SC} / \mathrm{mL}$ and above 750,000 $\mathrm{SC} / \mathrm{mL}$ resulted in yields of, respectively, $10.76 \mathrm{~kg}, 9.76 \mathrm{~kg}$ and $9.31 \mathrm{~kg}$ of cheese for $100 \mathrm{~kg}$ of raw milk.
Fat retention in cheese was not affected by SCC or TBC and these findings were similar to other reports with fat retention close to $92.5 \%$ (Saboya et al., 1998). However, protein retention in the curd was lower for cheese made with high SCC raw milk.

A regression equation to obtain theoretical yield of Minas cheese, based on dry matter yield is presented in Figure 4 and was calculated according to the Van Slyke equation (Van Slyke and Publow, 1921).

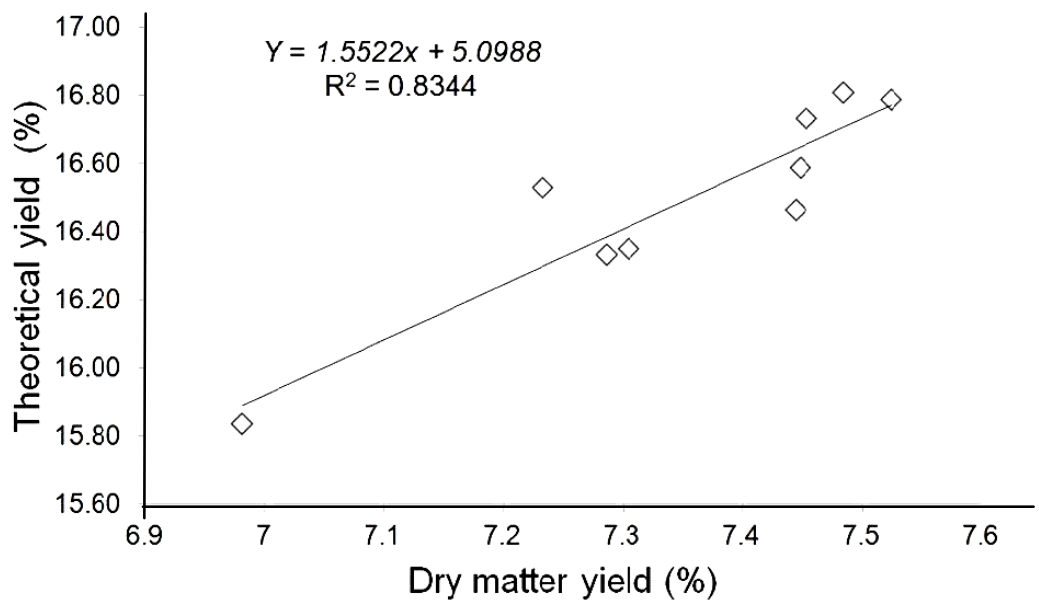

Figure 4. Theoretical yield based on dry matter after milk coagulation.

Average fat and protein content of milk, component retention in the curd and expected cheese moisture $(55 \%)$ for fresh Minas cheese were used (Brazil, 2004). The regression equation was $Y=1.5522 x+5.0988\left(\mathrm{R}^{2}=\right.$
0.8344 ), where $\mathrm{x}=$ dry matter yield and $\mathrm{y}=$ theoretical yield. The theoretical values were predicted using the equation: Yield $(\%)=$ Dry matter yield $(\%) *(1-\text { moisture content })^{-1}$. 
The methodology is feasible for cheese yield, since the correlation between theoretical values and predicted values was 0.9134 .

\section{CONCLUSIONS}

SCC was an important factor for cheese yield, with reduced cheese yield correlated with high SCC, as demonstrated by an empirical method. However, total bacterial counts did not affect the yield of the cheese curd. Protein content in the cheese whey obtained from raw milk with high SCC was higher when compared with the cheese whey obtained from milk containing low SCC, due to lower protein retention in the curd. Lower lactose content was observed for both the cheese whey and the original raw milk with SCC above $200,000 \mathrm{SC} / \mathrm{mL}$. A good agreement was found between theoretical yield values and predicted values, using an empirical method in reduced scale, with a high correlation value.

\section{ACKNOWLEDGEMENTS}

CAPES (student grant), CNPq (Proj. 578736/2008-0), FAPEMIG and LabUFMG.

\section{REFERENCES}

BENTLEY INSTRUMENTS INC. Bactocount 150 operator's manual. Chaska: Bentley Instruments Inc., 2002. 49p.

BRASIL. Instrução Normativa $n^{\circ} 4$, de 1 de março de 2004. Ministério da Agricultura, Pecuária e Abastecimento. D.O.U., 5 de março de 2004. Seção 1, p. 5.

BRASIL. Instrução Normativa $n^{\circ}$ 62, de 29 de dezembro de 2011. Ministério da Agricultura, Pecuária e Abastecimento. D.O.U., 30 de dezembro de 2011. Seção 1, p. 6-11.

CONNEY, S.; THIERMAN, D.; JOYCE, P. Effects of mastitis on raw milk and dairy products. J. Dairy Res., v.67, p.305-315, 2000

EMMONS, D.B.; ERNSTROM, C.A.; LACROIX, C. et al. Predictive formulas for yield of cheese from composition of milk - A review. J. Dairy Sci., v.73, p.1365-1394, 1990.

FENELON, M.A.; GUINEE, T.P. The effect of milk fat on Cheddar cheese yield and its prediction using modifications of the Van Slyke cheese yield formula. J. Dairy Sci., v.82, p.2287-2299, 1999.

HICKS, C.L.; ONUORAH, C.; O'LEARY, J. et al. Effect of milk quality and low temperature storage on cheese yield - A summation. J. Dairy Sci., v.69, p.649657, 1986.
MATIOLI, G.P.; PINTO, S.M.; ABREU, L.R.; et al. Effect of milk from cows with mastitis on the production of fresh Minas cheese. Revista do ILCT, Juiz de Fora, v.54, p.38-45, 2000.

MELILLI, C.; LYNCH, J.M.; CARPINO, S. et al. An empirical method for prediction of cheese yield. $J$. Dairy Sci., v.85, p.2699-2704, 2002.

MONARDES, H. Programa de pagamento de leite por qualidade em Quebéc, Canadá. In: SIMPÓSIO INTERNACIONAL SOBRE QUALIDADE DE LEITE, 1., 1998, Curitiba. Anais... Curitiba: Universidade Federal do Paraná, 1998.

SABOYA, L.V.; OLIVEIRA, A.J.; FURTADO, M.M. et al. Efeitos físico-químicos da adição de leite reconstituído na fabricação de queijo Minas frescal. Cienc. Tecnol. Aliment., v.18, p.368-376, 1998.

SAMPAIO, I.B.M. Estatística aplicada à experimentação animal. Belo Horizonte: FEPMVZ, 2002. 265p.

SMITHERS, G.W; BALLARD, F.J; COPELAND, A.D. et al. New opportunities from the isolation and utilization of whey proteins. J. Dairy Sci., v.79, p.1454-1459, 1996.

SOUSA, A.G.; NORONHA, J.F.; MOURA, C.J. et al. Influência da qualidade do leite sobre os custos de uma indústria de laticínios em Goiás. In: CONGRESSO DA SOBER - SOCIEDADE BRASILEIRA DE ECONOMIA, ADMINISTRAÇÃO E SOCIOLOGIA RURAL, 45., 2007, Londrina. Anais... Londrina: UEL, 2007.

VAN SLYKE, L.L.; PUBLOW, C.A. The science and practice of cheese making. New York: Orange Judd Company, 1921. 487p.

VENTURINI, K.S.; SARCINELLI, M.F.; SILVA, L.C. Características do leite. Vitória: UFES/PróReitoria de Extensão, 2007. 6p.

VIANNA, P.C.B.; MAZAL, G.; SANTOS, M.V. et al. Microbial and sensory changes throughout the ripening of Prato cheese made from milk with different levels of somatic cells. J. Dairy Sci., v.91, p.1743-1750, 2008.

VIEIRA, V.F. Características físico-químicas $e$ sensoriais de queijos Mussarela elaborados a partir de leites com diferentes contagens de células somáticas. 2010. 71f. Dissertação (Mestrado em Engenharia de Alimentos) - Universidade Estadual do Sudoeste da Bahia, Itapetinga.

WENG, M.H.; CHANG, C.J.; CHEN, W.Y. et al. Contribution of somatic cell-associated activation of plasminogen to caseinolysis within the goat mammary gland. J. Dairy Sci., v.89, p.2025-2037, 2006. 